\title{
Women at university. Strategies and achievements of a secular presence in Latin America and Spain
}

\author{
Consuelo Flecha-García ${ }^{1}$ and Alicia-Itatí Palermo ${ }^{2}$ \\ ${ }^{1}$ Universidad de Sevilla. Facultad de Ciencias de la Educación. C/ Pirotecnia s/n. 41013 Sevilla \\ e-mail: cflecha@us.es \\ ORCID iD http://orcid.org/0000-0002-1580-0428 \\ ${ }^{2}$ Universidad Nacional de Luján. Departamento de Educación. Ruta 5 y Avenida Constitución. 6700 Luján, Buenos Aires, Argentina \\ e-mail: aliciaipalermo@gmail.com \\ ORCID iD http://orcid.org/0000-0001-6365-1853
}

Submitted: 7 January 2018. Accepted: 3 June 2018

\begin{abstract}
This paper offers a descriptive and critical overview of the experience of the presence of women at university in Spain and several countries in Latin America. It focuses not just on how they embarked on different degrees, but also on the extent to which they went on to exercise professionally and the social barriers encountered at each step. It describes some of the strategies used on the paths followed to study at university during almost one hundred and fifty years, and the achievements made possible by this education, both inside and outside the academic setting. The paper draws on primary documentary sources from university archives and newspaper libraries and includes a review of the literature on the subject. These documentary searches provided us with a great deal of valuable information that has helped us in our task. The indicators of the subject matter studied are, amongst others, university education, female lecturers, history and sociology, female students and life aspirations.
\end{abstract}

KEYWORDS: History; Sociology; University; Students; Female lecturers; Knowledge.

Citation / Cómo citar este artículo: Flecha-García, Consuelo and Palermo, Alicia-Itatí (2019) "Women at university. Strategies and achievements of a secular presence in Latin America and Spain". Culture \& History Digital Journal, 8 (1): e002. https://doi.org/10.3989/chdj.2019.002

RESUMEN: Mujeres en las universidades. Estrategias y logros de una presencia secular en Latinoamérica y en España.- El artículo ofrece una mirada descriptiva y crítica a los inicios de la presencia de mujeres en universidades de España y de varios países latinoamericanos. Se centra, no sólo en el origen de su entrada en las distintas carreras, sino también en el ejercicio profesional y en la mentalidad social que hizo difícil cada uno de estos pasos. Se describen algunas de las estrategias utilizadas en diferentes momentos de las trayectorias seguidas para estudiar en las aulas universitarias -ya cercanas a los ciento cincuenta años-, y los logros a que les encaminó esa formación, dentro y fuera de los espacios académicos. Se han utilizado distintas fuentes documentales primarias procedentes de archivos históricos universitarios y de hemerotecas, y se han revisado los estudios publicados sobre esta misma temática; búsquedas que han proporcionado datos y circunstancias imprescindibles para elaborar este trabajo. Los indicadores de la temática desarrollada son, entre otros, formación universitaria, profesoras, historia y sociología, alumnas y expectativas de vida.

PALABRAS CLAVE: Historia; Sociología; Universidad; Alumnas; Profesoras; Saber.

Copyright: (C) 2019 CSIC. This is an open-access article distributed under the terms of the Creative Commons Attribution 4.0 International (CC BY 4.0) License. 


\section{INTRODUCTION}

The liberal States emerging in the western world at the dawn of the $19^{\text {th }}$ century as one of the consequences of the Enlightenment and the ideals of the French revolution, granted rights to the male population, as men had been chosen to occupy the public stage, be involved in socially visible activities and contribute to the desired changes of liberty and progress. They were summoned to take charge, and make personal use, of the new opportunities resulting from instruction (Puelles, 1993), and participate and achieve social protagonism. This was in part due to the desire to bury the dynamics of inequality inherent in the preceding absolutist regimes, turning the men who had, hitherto, been considered merely as subjects into citizens. This was an ambitious project with far reaching implications at a political, social, economic and educational level; and it was one from which women were excluded (Cruz y Díez, 2012).

The decision was taken not just to disregard the experience of women who had been dedicated to teaching and learning, but to exclude them outright from the schooling project which the condition of citizenship included and in which it was considered that they should not take part. School instruction was not the symbolic or real place envisaged for them in the design of the post-revolutionary project of modernity which was under construction. On the contrary, they were asked to accept as a requirement for the viability of this patriarchal dream, behaviours which involved domestic segregation, economic dependence silence in public spaces and few words in private.

But the incoherence underlying the universality with which these prerogatives were defined -principles of a generally male scope-, did not go unnoticed. Part of the female population manifested its disapproval with opinions and attitudes that underlined their determination to be covered by rights which could lead to new opportunities and improvements in their own lives. Great interest was generated by the debates over whether they should be accepted in spaces managed by state authorities. It is well-known that not all women allowed themselves to be dominated by the model that they saw reproduced around them. Not all women accepted this in their life projects or, at least, they avoided reproducing it identically. Because the criteria born under the patriarchy have not always been determinant, either in all female lives, or throughout the lives of all women.

In several countries, the political and social barriers designed to obstruct the entry of the first women into university became clearly defined. This level of education was not considered appropriate for women and there were also fears about the repercussions that their subsequent professional occupation could have on such an androcentric and hierarchical social order. However, female doctors, pharmacists, lawyers, secondary and university teachers, civil servants, etc. gradually demonstrated their ability to produce cracks in the patriarchal edifice; a mentality little given to accepting women in public settings and roles of importance, or to allowing them to abandon their preordained domestic roles.

\section{ORIGINS OF A HARD-WON LEGITIMACY}

In this context, a century and a half ago a group of young women achieved their goal of going to university despite unnecessary delays, legal obstacles demonstrating the exceptionality with which they were looked on, and cumbersome registration procedures. And above all, despite having to endure offensive and unfair comments around them from those who opposed them studying.

Drawing on documentary sources from libraries, university archives, and newspaper libraries, in this article we present a historiographic perspective of women's history with the history of education. We have written an account of the journey followed by female university students determined to change the direction of their lives, undaunted by the many obstacles in their way.

It is understandable that they rebelled against these incomprehensible difficulties which interfered with their progress towards education and earning a living. It is also worthy of admiration that they were able to overcome these obstacles, driven by an unquestionable conviction and by a lucid insistence which was impervious to frustration. They were brave pioneers who won legitimacy for the benefit of the generations that followed.

Since the creation of universities in the early Middle Ages, their objective had been to instruct laymen in knowledge for application in the erudite professions required by society; women were kept away from this place for knowledge transmission. It was only acceptable for study to be undertaken by women within the walls of monasteries due to their lifestyle; for all other women, it was unnecessary and inappropriate because they were not going to exercise such professions. However, we do find some cases of women who had completed exams or temporary teachers in 'one to one' university classes before the $19^{\text {th }}$ century. But it was not until the mid- $19^{\text {th }}$ century that the gradual incorporation of women into universities finally consolidated this path over three decades in many countries in the world. This continued absence over the centuries was not the result of laws prohibiting women from studying, or due to a lack of women with intellectual curiosity; it was instead the result of the destiny which had been imposed on the female population, and the negation of their intellectual capacities. This had effectively drowned women's liberties.

Thus, the second half of the $19^{\text {th }}$ century saw the registration of female students at universities in many Latin American and European countries, amongst them Spain. Even though this was not unprecedented, it was still met with disquiet. These middle-class women had decided to study in order to be able to work in the professions which were appropriate for their social group and which had hitherto been confined to men: their fathers, brothers, husbands or sons. The biographies of many of these women confirms that they sought access to a better qualified job for financial independence, personal satisfaction for the social service they performed, and as a platform from which they could become involved in public matters. In fact, apart from working in the profession they 
had studied for, most female graduates in the $19^{\text {th }}$ and early $20^{\text {th }}$ centuries became involved in activities which had important social repercussions.

Nothing could stop -although it could slow down- the growing number of women demanding changes to the indicators which were applied calculatingly to the condition of women, holding back their personal development. Studying was the objective which attracted many and, after that, they wanted to work in a profession, read, write, some wished to publish, and others take part in public life. These were channels for women's contribution to a cultural reality which, with different expressions and results, has run through the history of humanity.

This reticence was also made clear by portraying them as a special, minority type of youngster, due to characteristics of their personality, with unusual aspirations and support from families unaware of what they were doing. They were even accused of fleeing from their biological roles by going to university, because they did not feel satisfied with them. They were supposedly attempting to avoid submission to the prevailing sociopolitical project in which, for the middle classes, caring for the family and working outside the home were incompatible. This ideological model undoubtedly slowed down, and sometimes even prevented, the decision to study and find new ways of slotting into society; but it could not stop the continual increase in the number of women going to university, and that more countries and more universities followed suit.

The meaning transmitted by the image of exceptionality of these pioneers was intended to raise doubts, and perhaps even disquiet, among those young women prepared to break with the norm. However, it also increased perplexity amongst women regarding the customs that were imposed on them, and the segregating criteria that regulated their existence. This, in turn, increased the rate of transgressive responses. In an age of changing customs, it was becoming increasingly clear that common ground was being lost between what women wanted and what was expected of them.

The few female role models that were available were far removed in time, but they still illustrated brave, daring and insistent lifestyles which refuted the discourse about what women should be like, used as an argument to justify and maintain the prevailing status quo. When these points of view and personal positions arose, those around them tried to hide them from public curiosity, and they were censured to the point of the ridiculous and the protagonists were rejected as a threat to the male social pact of separation of spheres. However, these women were not always aiming for a complete break; their feelings and expectations were aimed fundamentally at broadening the scope of their personal liberty.

When they were denied access to university in their own countries, they often moved to others which did accept them, embarking on journeys towards ways of being a woman which did not involve renouncing more open and diversified horizons. Studies at university and the resulting professional careers with which they contributed to personal and social wellbeing, encouraged others to follow in their steps and gave legitimacy to the following generations of women at university, those who, over the course of the $20^{\text {th }}$ century, have sensed this acceptance, and corroborated the good results of well-made decisions.

\section{POLITICAL OPPORTUNITIES AND SOCIAL DEBATES IN LATIN AMERICA}

The advance in the construction process of national education systems introduced important elements in the way the citizenship is conceived and the citizens are formed. The influence of principles proclaimed by the French Revolution were affecting many government areas, being education among them. The ideas of French thinkers, as the Marquis of Condorcet and Claudio Helvecio, on how education could contribute to the country's progress and its social, economic, political and cultural development, were read with interest.

Taking these ideas to educational policies entailed passing rules that include a general, common, compulsory, free and universal education, aimed at all social groups and children. Good purposes with many difficulties in the way to the objectives pursued, since 'neither the degree of acceptance was homogeneous nor were the political and educational results deriving from its inspiration' (Rama, 1987). However, an elementary education started to develop, which among its main functions were socializing values and behaviours; and also offering a secondary and higher education for children in the government elite. Even though its application and practice had an uneven influence in many countries and in others, it became an effective means of social movement within emerging groups of middle classes.

In this context, girls and young women's education was part of the issues discussed in 19th-Century Latin American Geography. It was one of the consequences of the leading role, taken by many women socially well-positioned, in the initiatives to support the fight for independence. Support they had given offering all the means they disposed of to help a change of mind, to form opinion, to help the meeting and contrast; for example, with the evenings and gatherings they organized in their own houses, where they entwined social, cultural and political issues; but they also offer their help in hospitals and other areas of campaign, dressed as men so as to participate in actions of defense of their interests; as spies, as post officers, etc. Ultimately, taking sides in everything which bolster their expectations of independence (Navarro y Sánchez, 2004: 143-153).

These singular circumstances created a scenario where women could be more conscious of their capacity and the inevitable role they could have, proving themselves and their environment at the same time, that they were able to fulfill more functions than mere domestic and family ones. Individual women, but also in groups, such as the organization of Patriotas Marianas, founded in Mexico by Ana Iraeta in 1810, and the Charitable Society [Sociedad de Beneficencia] in Argentina or the Charitable Women Society [Sociedad de Damas de Beneficencia], 
created in 1923 by Bernardino Rivadavia prepared, among others, the way to claim and stand for women's education. Since the 19th century in many Latin American countries, one way or another, women who had had the opportunity to receive of receiving any cultural education, had to commit to different issues which affect women's population.

The idea of activism related to topics of general interest for women became popular. This continued in the first decades of the 20th century, ending with the second feminist wave of modern times, which influenced the reform of the civil code and established the right to vote for women (Navarro y Sánchez, 2004: 156).

And in this interdependence, which is inherent between education processes and the changes on personal consciousness, some women, still a few at the end of the 19 th century and the beginning of the 20th, broadened their horizon of expectations. They claimed for more and better education, but with reticence on the part of their environment, which needed them for family duties:

When in the decade of 1880 , women's education became an issue of national interest, many voices claimed for 'higher' education, to let women be part of professional careers. However, many educators did not lose sight of the need to prepare women with more limited objectives, such as home effective administration and the 'scientific' care of children (Labrín, 2005).

Periodic press, which increases in number of headings and publications, has dedicated since the beginning of the 19 th century space to voices, which strengthen the discussion over the advantages and disadvantages of women education. The Mexican Newspaper [Diario de México] frequently refers to the problems posed by women who are not docile, those who think they know. We can find this expressed in poetry and narrations of several numbers of the years 1806 and 1807. In Argentina issues related to women's education were present in several newspapers; in Commerce Correspondence [Correo de Comercio], founded by Manuel Belgrano in 1810, in July of that same year and, in two consecutive numbers; it is considered that the foundation of girls' public schools is one of the most urgent and important tasks, authorities must accomplish in a 'new country' to form them in good practices, 'main purpose for which they are destined'. To this end, 'donations from distinguished citizens devoted to women's education' were encouraged to be effectively made. ${ }^{1}$

Twenty years later the newspaper La Aljaba was published, to be the first women's newspaper in Argentina. It devoted continued attention to the issue of women's education. Here, we observe only two of the articles, the one in number 3 of the magazine of November 1830, about 'Daughter's education'; where it was claimed that they had been prohibited 'until they learnt all letters in the alphabet' ${ }^{2}$ and in the following number, another one dedicated "To those who are against women's instruction', and which started with the question 'Up to which moment will females be plunged in the darkness where the oppressive system, of those who denied the simplest knowledge, have taken them?'?

By the middle of the century, from January 1852 to December 1855, we found in Brazil the newspaper $O$ jornal das senhoras, which came out with the purpose of contributing to women's moral autonomy and its progress within society. In the last third of the 19th century, there was an important Brazilian feminist press: O sexo femenino, 'dedicated to women's education, instruction and emancipation'; O domingo, Jornal das Damas, Myosotis and Eho das Damas (Navarro y Sánchez, 2004: 159).

A costly but necessary course of discussions and perseverance in the itinerary towards university education in Latin America, until it was accomplished with almost fifty years of distance with the first graduates in the United Stated, and less than twenty in the case of certain European countries (Bieber and Heppner, 2015).

\section{First Latin American University Students}

The enrollment of female students in Latin American universities started in the decade of 1880 and, as in other Western countries, it was the Medicine School the mainly chosen by the first young female students, who decided to start their university studies. A decision, which might have different reasons, although according to Karen Offen there are two main reasons in those years: 'firstly, the campaign for women's medical education and, secondly, the development of a well-documented review about the important disadvantages related to women's employment' $(2015: 207)$. To which we should add the rivalry to control knowledge when male physicians were taking on responsibilities and practices in areas commonly assisted by midwives. The same professor Offen stated that 'in the campaign of medical education nothing less than knowledge and the control over women's bodies and reproduction were compromised' (2015: 208).

So as to be part of academic spaces those female youths use the strategies they could; they expressed their will and claims publicly, they traveled to other countries where they could enroll in medicine; they pursued legal remedies, they created 'Women's Medical Associations, among others (Palermo, 2006). At least six Latin American and Caribbean countries enrolled women in different careers in the last two decades of the 19th century; Argentina, Brazil, Chile, Cuba, Mexico and Peru.

Brazilian María Augusta Generoso Estrella traveled to the United States to study medicine in the New York Medical College and Hospital for Women (NYMCHW), founded in 1863 by a supporter of women rights, Clemence Lozier (Taylor, 2003). She graduated in 1881 and after she had worked as an intern for a year, she went back to Brazil; once she had validated her degree at Rio de Janeiro University she devoted herself to medical practices. When she was a student together with another Brazilian student of the same School, Josefa Águeda Felisbela Mercedes de Oliveira, she decided to publish in 
New York, the literary newspaper The Woman. Devoted to the Interests and Rights of Brazilian Women (Davidson, 2014); it was thought to convince Brazilian women of their capacity to study, and was distributed in Brazilian biggest cities. On its pages the benefits of female dedication to medical care were claimed, since there were women who did not accept being treated as men. They benefited, thus, with the fact that they knew they could be assisted by other women; and with them all society benefited (Rago, 2000).

Being pioneers in Latin America, they experienced the same which had happened to other female youths in Europe, they had to leave their countries looking for universities, where women were admitted. Knowing which experiences were being produced would encourage new female youths to ask for enrollment at universities in their own countries, and these centres would have to admit them in the end. Being Chile one of them and, in response to the discussion about the need to strengthen a broader education for women, in 1877 the Minister of Justice, Worship and Public Education by then, signed a decree in Viña del Mar, on February 6th, published with the heading 'Women's exams to obtain professional degrees'. ${ }^{4}$ This decree established 'that women must be admitted to sit for binding exams so as to obtain professional degrees as long as they are bound to the same rules the men are subject to'. Previous considerations related to regulations, described the convenience of 'encouraging women to complete solid and formal higher studies'; of 'the fact that they could practise some professions, the so-called scientific ones, with certain advantages'; of that 'which is important is to help the means so they could earn their own living'. Several years had passed since Antonia Tarragó and Isabel Le Brun, secondary school directors in girls' schools of Santiago de Chile, decided to ask for a court, where their female students could sit for their binding exams to access University and, from the echoes these requests were having in the press (Sánchez Manríquez, 2006).

Having passed four years of the publication of the Decree, the enrollment of female students started in Santiago de Chile University. The first three -Eloisa Díaz, Ernestina Pérez and Matilde Throup- had already been students in the Isabel Le Brun de Pinochet Lyceum, established in Santiago in 1875, where the first exams for Bachelor's degree had been prepared (Lyceum, 1900). Eloísa Díaz Insunza studied Medicine and Pharmacy from 1881 to 1886 and on January 2nd, 1887 she got her degree as Doctor of Medicine and Surgery (Jiménez, 2000), being the first woman in South America to get a degree in a Latin American university. In the memoirs she presented to graduate, she described many specific situations she had dealt with up to that moment; and she denied the dangers spread by doomsayers with these words:

Some have whispered, some other have disapproved, and those who have applauded, have been a few or many? [...] I feel when I concentrate intimately that I have not lost including myself (sic) that I have not di- minished my woman's dignity, nor have I changed the temper of my own sex! No! Instruction, as many pretend it to be, is not a downfall for a woman: it is her salvation (Díaz, 1888).

Ernestina Pérez Barahona also graduated in Medicine on January 6th, 1887 with a memoir about 'Popular hygiene'; later she completed her education in Germany for two years-where she had to sit in class next to the professor and sometimes behind a screen-, due to a scholarship granted by the Chilean Government and, during two other years in Paris. Along her professional career she combined medical practice with research and publications (Orellana, 2015). The third, Matilde Throup Sepúlveda finished her Law studies in 1892 (Sánchez Manríquez, 2006). And even before the century ended, in 1898, Matilde Brandau Galindo read her thesis in Law, having chosen the topic of Women's Civil Rights, in which she exposes a comparative analysis on the legal situations suffered by women in different countries (Brandau, 1898). She continued working for women's rights and, education was the professional field she finally devoted to.

Female researchers, who have studied 19th-century female physicians in Mexico, describe a female student called Zenaida Ucounkoff who sat for her thesis exam in 1877 , but of whom there is no proof of her studying in that School (Flores and Ramos, 2000). The inquiry to the Mexican Medical Gazette [Gaceta Médica de México] in that year offered precise information about this fact: "Miss. Zenaida Ucounkoff has just suffered (sic) her exam successfully; her thesis was: "Ether paper in subcutaneous injections, and its usage to substitute blood transfusion",; a protagonist we had lost any track of.

In the Mexican University a female graduate got her Bachelor's degree in 1887; Matilde Petra Montoya Lafragua, also in medicine, after having to overcome comments and situations which discredited her behaviour. Having finished her studies as a midwife in the School of Midwives and Obstetricians, she enrolled in the School of Medicine of Puebla, which she abandoned due to the social rejection set off. She was admitted in the National School of Medicine where the objection of teachers and students leaded to the withdrawal of that admission based on the fact that the School's internal regulation referred to male students, not female ones. She wrote to the President of the Republic who gave the necessary instructions by means of a decree, dated August 24th, 1887, so Matilde could finally sit for her exams (Carrillo Esper et al., 2015). She graduated presenting a thesis on 'Lab techniques for certain clinical research'. She was part of Mexican Medical Associations and the Women's Ateneo; in 1923 she participated in the second Pan-American Conference of Women celebrated in Mexican City (Castañeda and Rodríguez, 2010).

The second student started in the following decade, primary education teacher Columba Rivera Osorio, who finished her Medicine studies in 1899 (Flores and Ramos, 2000 ) with a thesis on 'A gynaecological issue. The precision and accuracy in the diagnosis of abdominal tumors 
can only be reached in most cases through laparotomy'. And as her predecessors, she realized that women who resort to her assistance did not want to be treated by male physicians. Her professional practice became evidently education-oriented, since apart from working for Juárez Hospital, she also worked as professor in the National School of Medicine, female physician of the Anthropometric Department of the National Preparatory School and medical inspector for the Normal School for Professors (Castañeda and Rodríguez, 2010). Together with the lawyer María Sandoval de Zarco and a teacher of the Normal School, María Correa Zapata, they created the magazine The Mexican Woman (La Mujer Mexicana) which offered articles and information about women's rights and expectations. In the first number, making reference to Columba, it was said: 'Anyone who knows Miss Rivera will be convinced that knowledge does not kill nor poisons' (Macías, 2002).

In Brazilian universities, Ermelinda Lopes de Vasconcelos graduated in 1888, in the School of Medicine of Rio de Janeiro. She had enrolled four years before, after persuading her father to give his consent. She was a teacher and chose as topic of her thesis 'Clinical forms of Meningitis in children: differential diagnoses'. In light of her graduation, a well-known historian and writer of the time, Silvio Romero, published a report under the heading 'Female macho [Machona]' where it said: 'Be sure female physician that your macho feet will not step on my place', (Colling, 2011). An year before Rita Lobato Velho Lopes had finished her studies in the Medical School of Bahia University, in the middle of a local press campaign guaranteeing that, for example her brain had not enough capacity to assimilate medical science or, that there wasn't any man who would like to marry her. Even in this context, she became the first female youth formed in a Brazilian university and, later, the first councilor of Rio Grande do Sul (Colling, 2011. Boa and Costa, 2005). In 1884, with only fifteen years old, Antonieta César Dias started her studies in the Medical School of Rio de Janeiro; she was the third to do this in Brazil, and finished defending a thesis work on 'Post-partum Haemorrhage' in August 1889. She received support of part of the press, the one committed to women's rights, such as the newspaper The Family (La familia), which rated Antonieta's graduation as something 'more of a victory of the sex she represented, over brutal prejudice of stunting education, unfortunately still in force' and, that her achievement reinforced 'the most vehement protest against opinions opposing our emancipation' (Colling, 2011).

In the island of Cuba, there was a group which coincided with the beginning and ending of their university studies between 1883 and 1888. Mercedes Riba Pinos, enrolled in the School of Philosophy and Literature in La Habana when she was 26 years old; she had been born in Barcelona, Spain and got her Bachelor's degree in 1885. Two years later, in May 1887, she defended her doctorate thesis in front of the General Body gathered 'in the University Lecture Hall to confer on her a Doctorate degree in Philosophy and Literature' (Hernández, 2012). Fran- cisca de Rojas Sabaret, a twenty-six-year-old teacher who was born in Cienfuegos, started her studies in the School of Law and finished in 1888. There's still a third woman, who studied in the School of Science; a fifteen-year-old youth called Digna América del Sol y Gallardo, native of Matanzas, who got her Bachelor's degree in Science, Physicochemical Section, in 1888. There were still more applicants in the Pharmacy School. The first being María de la Asunción Menéndez de Luarca Díaz, native of Guanabacoa (Marchante and Merchán, 2012).

She entered in the School of Medicine and Surgery and in the School of Science, Laura Martínez de Carvajal y del Camino, and graduated in 1888 as Bachelor in Science, Physicochemical Section and, in 1889, as Bachelor in Medicine, specializing in Ophthalmology. Her professional activity was intense because she practised in a Polyclinic, created the Polyclinic Files Magazine [Revista Archivos de la Policlínica], took part in the drafting of the text Clinic Ophthalmology [Oftalmología Clínica], was a teacher and created a free school for poor children and an asylum for the blind (Kohn Loncarica and Sánchez, 1996 y 2000). One of her professors, the lecturer on Surgical Pathology José Púlido Pagés, referred to her stating she behaved, according to what he understood was correct for a woman, earnest, conscientious and humble, and her classmates behaviour had always been fraternally respectful of her. In case there was any doubt about the truthfulness of the excellent marks she got, she made clear they were not a result of teachers' education gallantry, but of justice, which appreciated the study and mastery of knowledge (López, 2004).

Until 1898, year in which Spanish independence was declared, there were many women undergoing university studies; mainly in Pharmacy, but also in Law, Science and Philosophy and Literature. Some also defended their Doctorate thesis, such as María Jesús Pimentel Peraza and María Teresa Pérez Chaumont in Pharmacy, and María Luisa Dolz in Natural Sciences (Hernández, 2012).

In Peru, Cusco University received the first female student, Trinidad María Enríquez, in the School of Jurisprudence, where she got a Bachelor's degree between 1875 and 1877 , although she was not conferred the right to get her degree (Gutiérrez, 2005). And, in 1888, Margarita Práxedes Muñoz entered San Marcos University of Lima, a woman from a family link to politics and brought up in an intellectual environment, who got her Bachelor's degree in Natural Sciences in 1889; then she traveled to Santiago de Chile, where she studied in the School of Medicine and finished in 1895. Laura Esther Rodríguez Dulanto enrolled in the School of Science of San Marcos University in 1892, and after she got her Bachelor's degree she enrolled in Medicine while she devoted some time to prepare her Doctorate thesis work. She defended it in 1898 on 'Geographical studies of Chancay province'; she became the first woman with a doctorate degree in Peru and a professional dedicated to different fields (Díaz, 2007). Before the end of the century, in 1899, Esther Festini de Ramos Ocampo enrolled in San Marcos School of Literature, and took advantage of her mandato- 
ry degree work so as to moot her ideas about women's situation. She chose as heading 'The role women have in society determines their education'. In 1904 she defended her Doctorate thesis work in Literature on 'Issues related to women's education' (Valladares, 2012).

Women, whose among their expectations were their university studies, looked for a way to undertake them. From a country to the other, the possibility was allowed for those who were willing to devote effort and constancy.

\section{Women's Access to University in Argentina}

As in the rest of the countries, Argentina was not out of the discussion about women's enrollment in university studies, its convenience and the women's capacity to undertake these studies. It was not enough that the Constitution of 1853 established equal rights for men and women. Nor had been useful the opinions in favour of women's education along the 19th century, Those of Belgrano since 1810 in the pages of the newspaper he had founded himself Correo de Comercio; those of the American $\mathrm{Ob}$ server (Observador Americano) since 1816, year in which an article from its August number on 'Women's education' came out, stating: 'If passion does not mislead us, we could make sure that there will only be a few countries to regret the lack of interest to educate the beautiful sex, as will our provinces', ${ }^{6}$ Those of female journalist and poetess Petrona Rosende in La Aljaba, dedicated to the beautiful sex since 1830. In the second half of the century, there were more intense disputes, which enjoyed full support of Domingo Faustino Sarmiento. Period in which there was also a change of perspective added to the news deriving from the countries, where women were studying at universities.

Encouraged by the context, wills started to exert among Argentine youths. The first was Élida Passo from Buenos Aires, who enrolled in the School of Humanities and Philosophy of Buenos Aires University, having also sat for exams of other subjects in the School of Exact, Physical and Natural Sciences. Maybe as being the daughter of a Pharmacist, she got her degree in Pharmacy in 1885 , a career which, by then, was not part of university studies. To continue her formation, as intended, in the School of Medicine she had to pursue a legal remedy to support her request, although an early death hindered her to finish her career.

In those years Argentina counted on two universities, one in Córdoba and the other in Buenos Aires, where students could enroll in four different careers: Medicine, Law, Philosophy and Literature and Exact, Physical and Natural Sciences. Among the female youths who started their classes, Medicine was the most widely chosen; the story of the first female university graduates with professional practice, is that of physicians, dentists, pharmacists and obstetricians, in almost every country. The same happened in Argentina (Palermo, 2006. Sánchez et al., 2015).

The first woman who got a higher education degree in Argentina was Cecilia Grierson, when she finished her Medicine career in Buenos Aires University. Élida Pas- so's legal remedy had paved the way so she did not have any problems with her enrollment. She had some work experience as governess and teacher, for what she had prepared herself in the Buenos Aires National School of Teachers, headed by Ema Nicolai de Caprile, one of the teachers, who Sarmiento had taken to Argentina (Barrancos, 2000). Cecilia Grierson was a creative and enterprising woman who in 1886 , being still a student, in light of the situation triggered by a cholera epidemic, created the Buenos Aires Medical Board [Cículo Médico de Buenos Aires], the School of Nurses [Escuela de Enfermeras] considered to be the first in South America; a centre she headed until 1913, maintained when it was necessary and which was given her name a year after her death (Flecha García, 1993). As a professional she performed several functions and cooperation; she tried to be a professor in the School of Medicine, but she was not admitted, about which she states: 'the reasons and arguments exposed in this occasion, would complete a chapter against feminism, whose intellectual and economic aspirations I have always stood for' (Grierson, 1916).

Another Argentine youth, also a teacher, traveled to Switzerland in 1879 and got her degree in Medicine in Zurich University, centre to which women from different countries were transferred to study, due to the good way they were received there. She was called Petrona Eyle and was a descendant of a Swiss family, which it might be a favourable reason to start such a journey. The thesis work, written in German and dedicated 'as a token of gratitude' to her father, a military surgeon, reinforced her will to go back to her origins. When she finished her studies she went back to Buenos Aires and validated her degree. When, in May 1910, the First International Women's Congress was held in Argentina, Petrona Eyle was the president of the 'Argentine University Students' Association' and, organized the Congress (Carlson, 1988).

Before the end of the century, Elvira Rawson Guiñazú enrolled, once again with previous studies as a teacher. She graduated in 1892. Being a colonel's daughter, even during her studies she showed a social and political commitment, which she kept all along her life, organizing a field hospital together with her classmates to assist people injured in the civil-military revolt of 1890, known as Park Revolution. She also differentiated due to her position to defend women's rights.

Towards the end of the century, she tried, with no luck, to study Law. The magazine Anales de la ciudad de Buenos Aires informed about the existence of a youth, who sat for 'most' subjects' exams of the first year without attending classes at the Schools of Law and Social Sciences of Buenos Aires University; but it will not be until the 20th century, in 1909, when Angélica Barreda finished her studies in the School of Law of La Plata y Celia Tapia in 1910, in Buenos Aires (Suárez, 2012). The difficulties in the professional practice of Law on the part of women contributed to the fact that less women chose the career.

In 1896, the School of Philosophy and Literature was created in Buenos Aires University. Besides, it was an op- 
portunity for the teachers who wanted to undertake higher level studies -they could enroll with no more requirement than their teachers' degree-, which produced a reorientation of women university choices. Since the beginning of the 20th century there were more graduates in this School than in the one of Medicine; it was the beginning of a period characterized by the concentration of women in other studies. In the first graduating class, in the year 1901, there were four women out of nine graduates. María Atilia Canetti, Ernestina López, Elvira López and Ana Mauthe (Palermo, 2006).

We can compare this situation with what happened with teachers' education, the studies and the profession, in which 'there was a great and unusual political insight to detect the emergence of certain women's movement, allow for an institution and channel it to the direction desired by domain groups' (Morgade 1997). The School of Philosophy and Literature called for women to its classes, and offered, at the same time, the chance to access university, working as a segregated zone for women and an election according to 'women's nature'. It also had a low number of students, since a few men wanted to carry out an activity barely profitable. Arguments which, for the thought of the time, made this School into an ideal option for women, since it let them study with no need to have professional practices and, least of all, earn money (Palermo, 2006).

\section{The First Universities and the Awakening of Consciousness}

The presence of women in university classes during the 20th century must be framed in the general context of immigration growth in Latin American countries, the development of a liberal project for modern societies and the predominance of positive strands of thought among intellectual groups. Gloria Bonder (1992) stated that immigration flows coming from Europe since the end of the 19 th century cherished values which admitted, and even foster, women's education. A great part of those families expectations of integration in the new countries and of social and economic mobility were on the new generations, sons and daughters.

So these universities became a familiar space where improvement efforts prevailed in terms of education needs. Other women studied careers, Dentistry, Pharmacy or Obstetrics, whose professional practice was shared with parents, siblings or husbands, which surely was an important support.

Studying at university took a double meaning: from the point of view of the established order, it was a narrow door through which only a few access and having problems. But from women's point of view it was a wide door they took advantage of, to form themselves, enter a profession and be able, when going through the door, to participate actively in social, political, economic and cultural life of their time.

Even being not many women in university classes, they were active in debates, congresses and publications, spreading out an important movement in favour of women's demands; and maybe it could be said that they even represented a precedent of gender studies in some of the countries. In other words, with those women new theoretical and practical concerns appeared because of gender relations fostered by women's movement and the general discussions of the time. The fact of having been pioneers made them think about the place of 'exception' they had. A circumstance which was not exclusive of Argentina. When Dorotea Erxleben graduated as physician in Halle University in 1754 , the topic she chose for her thesis work was the 'Analysis of causes which make women draw themselves away from study' and her successors continued working on the same issue in their thesis or in other subsequent writings.

\section{PIONEERS IN SPAIN}

If we look at events in Spain, during the Sexenio Democrático (1868-1874) a small number of girls requested access to baccalaureate studies -the first in 1870-, and the first women entered university in 1873. These initial steps made a significant contribution to breaking down certainties about the correct educational model for women, and led to an evolution in mentalities about how to perceive the intellectual capacity of women. By the end of the 19th century, the number of women who had been to university was scarcely fifty. Only nine women registered in 1900-1901 in the ten universities existing in Spain at the time. Of these, five studied medicine, two pharmacy and the other two philosophy and letters, representing $0.05 \%$ of all university students (Flecha, 1996: $150)$. The regulations were that they were enrolled as free students, only going to the Faculty to sit exams. If they wished to attend lectures as official students, they had to apply for permission to the authorities of the ministry responsible for affairs of public instruction.

These young women had these aspirations at a time when most of the Spanish population could not read, let alone write. As these women started to enter universities, the literacy rate among the female population was barely $10 \%$. This rate was beginning to increase as a result of the Law of Public Instruction in 1857 in which the Minister Claudio Moyano made it obligatory for there to be a school for girls for every 500 inhabitants. This measure was effective in gradually raising the rate of female literacy from $9 \%$ in 1860 to $25 \%$ in 1900 (De Gabriel, 1997: 203). The number of girls at primary school increased steadily and they had schools in their places of residence.

However, other levels of instruction were still almost a privilege for women; only a minority studied in normal schools for women, or did the exams to gain the title of midwife, or trained for trade jobs or for the task of governess: types of education for women which were too closely linked to the historically conditioned system of gender relations. But, even so, they became an effective launch pad for those who wanted to lead their lives with other points of reference. Given these conditions, it is hardly surprising that women attending secondary school 
or university caused much consternation. In the middle classes a growing number of women wanted and needed paid employment and they therefore required the training that would allow them to choose from those performed by their social group. There were no lack of situations and personal and family interests which leant towards this option. One of these was the possibility of remaining unmarried, either out of choice or through a lack of a suitable match, which would make it necessary for them to have financial resources of their own; if they did not manage this, they would have to depend on the support of family members. It is also true that when married, their own income also protected them against a total dependence on their husbands.

\section{Barriers and Strategies to Overcome Them}

María Elena Maseras Ribera (Vilaseca, Tarragona, 2505-1853/Mahón, 04-12-1905) started at university in 1872-1873; in her first year in the non-official form of study and later, when a new regulation came into force, attending lectures. She continued her degree without difficulties until, after passing all the degree courses, she decided to move to the University of Madrid to do a doctorate. To do this, she needed to apply for her degree certificate which officially recognized her studies to be able to exercise professionally. It was at this moment that all sorts of obstacles appeared due to the fear of women taking up remunerated employment, along with the autonomy and freedom that this would entail. There was concern that these young women with excellent marks would not be content with having assuaged their intellectual curiosity in the degree they had just completed. It was feared they would set themselves new goals which would affect the division and allocation of hitherto separate and sealed social spheres.

Hence, those with the role of judging the pertinence of these studies for women took several years to issue a response for something there was no will to accept, despite it being their right. During the lapse in time, two more women doing the same degree at the same university applied for the same certificate: María Dolores Aleu Riera (Barcelona, 1857-1913) and Martina Castells Ballespí (Lérida, 1852-Reus, 1884) (Camps y Casasus, 2000). The official response finally came in March 1882 via a Royal Order which recognized that it could not deny the degree certificate to the three women; this right extending to all female students registered at that date in Spanish universities. However, the same law prohibited access to new female students, in a clear indication that these three were exceptions and, as such, their passage through university was not to be copied by others.

The first student, María Elena Maseras Ribera, had written to King Amadeo 1 of Spain in 1870 requesting permission to perform baccalaureate and then university studies. There was no rule prohibiting this, but women knew that this did not necessarily mean that they could study. The customs, mentality, and prejudices about the status of women were stronger than any ministerial regulation. The king swiftly communicated his approval through the General Directorate for Public Instruction authorizing Elena Maseras to take the baccalaureate exams, although it did not mention exams at university; although this did not stop her from taking those as well (García, 2010).

From 1882 to 1888 Spanish universities were not allowed to continue accepting women. Only the University of Valencia breached this rule, probably because it was unaware of the legislation. When this right was reinstated due to the insistence of more young women, it included the application to the Ministry for a special permit to be able to attend classes: this permit was only issued if the professors of the subjects could guarantee "order in the classrooms in which these young ladies attended". This measure reflects the disquiet that the presence of female students must have caused in those who had to authorize them; and it probably also worried the young women themselves and their families, discouraging them. This precaution confirmed the idea of the male nature of lecture rooms and the risk that the introduction of females could involve. This thinking was clearly the fruit of an archetypal male imagination for the prevention of rash behaviour, or perhaps it stemmed from experiences about the reaction of male students to the presence of females in an institution they considered to be their own.

The academic records of these female students reflect that the lecturers responded in all cases by accepting them in their classes. They were not asked about the female students' capacity to study the subject in question, or whether they agreed with admitting them to university. With their signature they committed themselves to guaranteeing order in the classroom when a female student was present. It appealed solely to the lecturer's authority in front of his students, which could have helped female applicants. It is hard to imagine a professor admitting that he was incapable of keeping his students in order. As the years passed, it became clear that lecturers saw the presence of women as something normal, and there were even academic advantages: "The intention of this person seems perfectly fair to me and I find no reason for denying her access to it. 9 October 1893. Miguel Morayta". "The undersigned has been Professor of General Literature of the person in question and may certify that not only was there never any occasion or pretext for altering the order of the class, but her presence, behaviour and application served as a stimulus for the less fortunate students. 30 September 1894. Antonio Sánchez Moguel”.

But this was not enough, and they were also subjected to other complementary measures to safeguard the order that could be jeopardised, not just in the classrooms but also in the corridors. Of the different accounts that have been left to us, let us look at two. One comes from María Goyri (Guecho, Vizcaya, 1873-Madrid, 1954) who was to become a researcher in history of literature together with her husband the philologist Menéndez Pidal. She was not allowed to wait for the start of class either in the corridors or in the classroom, but in the staffroom to be accompanied to the classroom and be seated on a chair near the lecturer, and then accompanied back at the end of the 
class (Carabias 1997: 124. León, 1998: 89-90). Twenty years later, another account comes from María Dolores de Palacio Azara (Zaragoza 1895-Ávila, 1989) at the Faculty of Philosophy and Letters of the University of Zaragoza. She tells of her experience in 1915: "To ensure I didn't go alone, my parents found a young German lady, Barbara (the Catholic Fräulein Barbara came from a colony of Germans from Cameroon who settled in Zaragoza in 1914) who would accompany me to class and come back with me afterwards. It was the Great War and it was easy. When I got to the university they shut me in the small room the janitor had for keeping the brooms and cleaning things. When classes started I would leave the room and sit at a desk separated from the other students" (Palacio de Azara, 2010: 12). All these precautions, including waiting amongst the cleaning things, were taken to maintain the distance between male and female students, transmitting the idea of isolation in reaction to the unprecedented nature of these audacious females, and legitimizing two models of education traced in a dichotomy and distributing the differences between men and women hierarchically, with clear repercussions in the public arena where men had to continue appearing as the only actors.

María Elena Maseras cleared the way for the fortyfour young women who went to Spanish universities before the end of the $19^{\text {th }}$ century. Of these, thirty-three obtained the degree certificate. Only eleven, 25\%, did not finish their studies for very different reasons. Eighteen finished Medicine, this was a majority perhaps because health and care were roles that women had always assumed within the family, and many outside the family, over the centuries. Eight studied Pharmacy -one doing Medicine afterwards-, and eight studied Philosophy and Letters. During the following decade, 1900-1910, another thirty young women went to university, twenty doing the same degrees as the aforementioned, apart from one who studied science. Thirteen studied medicine, four pharmacy and two philosophy and letters (Flecha, 1996: 149-157).

From the start of their university degree courses, some of these women had their sights set on going on to complete a doctorate, ${ }^{7}$ an academic level which was virtually exclusive to those postgraduates who wished to become university teachers. A doctorate did not fall within the scope of women because the regulations which controlled access to public work, while not prohibiting it directly, did not contemplate it explicitly. ${ }^{8}$ Nine female postgraduates drew up the research project to present and defend it as a Doctoral Thesis. They wanted to be prepared when that moment presented itself. Some inner feeling moved them to reach the highest level of academic education in Canarias (González Pérez, 2012), Valencia (Verdugo, 2013), Salamanca (Prado, 2015), Zaragoza (Miqueo, 2015), de Palencia (Juan, 2015), Andalucía (Flecha, 2016) o Lérida (Casals, 2017).

Ángela Carraffa de Nava (Valladolid, 1873-Salamanca, 1950) was one of them. She defended her thesis in Philosophy and Letters in December 1892 and three years later wrote to the Minister of Development -under whom public instruction depended-, claiming the right to exercise as a teacher in normal schools, which is where teachers received their initial training. In her letter she emphasized not legal issues, but customs and beliefs which were still prevalent. She argued that "While it is recognized that women can obtain academic qualifications and even a $\mathrm{PhD}$, they are not given the right to aspire to roles in higher and secondary teaching, perhaps due to doubts about their suitability for undertaking these roles" (Flecha, 1996: 193). Reaching the highest academic level and with excellent marks did not liberate them from the shadow of doubt about a natural lack of aptitude or the undesirability of having women occupy spaces which did not correspond to them.

\section{The will to be Instructed and to Instruct}

Not all the characteristics assigned to women were generalized, nor were all the results the same, nor can we believe that they were applied universally to women in each society and in each culture. This reality means that we can contemplate a wide range of responses to the different ways women have lived in society through history. Furthermore, in the education received by women, there was something more important than the literality of the messages; I am referring to the sense and meaning that each receiver gave to what they heard, the symbolic setting from which they processed this information, the different ways this affected them in the decisions about themselves.

Although the weight of customs was so strong that it prevented the advance of demands being made by feminism, as the writer Emilia Pardo Bazán declared in 1914:

One has to acknowledge that governments have done what they have been able to. Any woman who wants to can study, go to university and do whatever degree she wants; the problem is that they don't go, and there is even the Burell decree which allows women to exercise any role in the ministry of Public Instruction. No, no; the stagnation of feminism in Spain isn't the government's fault, it's the fault of customs, they shrink back, they are whimpish: and here, where no woman thinks it's bad to dance a tango, for example, they would not think it right to go to university classes to study Logic and Ethics (El caballero audaz, 1914: 9).

She had proposed acting in a heterodox manner to open doors by doing, as she says, "things that are forbidden to women". She highlights, for this purpose, all the posts and honours she has accumulated:

My work to open the doors in Spain to feminism has been solely personal: setting the example of doing everything that I can, everything that is forbidden to women. I have had the pleasure of being the first woman to be a numbered member of the Ateneo; the first woman president of the Sección de literatura; the first and only woman to have been a professor at the Escuela de Estudios Superiores, in the Ateneo itself; the first numbered member of the Real Sociedad Económica Matritense de amigos del País, and other posts (El caballero audaz, 1914: 9). 
It is revealing, in this sense, if one thinks about what it meant for middle-class women to enter a level of education, gaining academic qualifications, and going on to professional jobs hitherto reserved for men with skills and social origins like theirs; the resistance which, as we all know, were encountered by virtually all those who wished to receive a university education (Flecha, 2006: 455-485). We should not forget that in the preceding centuries, it had been the mentality and the customs, not the laws that had led to their absence in most circles of erudite culture: that acquired in books, manuals, treaties; and this was accepted as the only framework of authority and representation of the world. Hence the scarce production by women in these areas of knowledge which responded to the criteria of what was intellectually relevant. Although some women had managed to overcome the obstacles which distanced them from this objective. In Italy, at the University of Bolonia, Bettisia Gozzadini (1209-1261) (Addeo, 1939: 23-30), obtained a degree in Law, as did Dorotea Bocchi (1360-1436) in Medicine. In Spain, at the beginning of the 16th century Luisa Medrano (1484-1527?) gave some lessons; at the University of Alcalá classes were given by Francisca de Lebrija and Isabel de Vergara (Rivera, 2005:152). In 1587, the author from Albacete, Oliva de Sabuco, published the treatise on La nueva filosofía de la naturaleza del hombre [New Philosophy of Human Nature], which reached eight editions, etc. (Rivera, 1997: 131-146).

\section{In the Patio or in the Square? Degree and Profession}

As a student, María Goyri made a well-known address when she attended the Hispanic-Portuguese-American Pedagogical Congress in Madrid in 1892 where she had to defend the speech on women by Emilia Pardo Bazán. She highlighted the futility of men's resistance to women's incorporation into professions which had hitherto been theirs exclusively. "Men's fear that we will compete with them, reminds me of the cigar workers' reactions to the introduction of machines; they screamed...; there's no question what the result will be; you can't stop progress" (Goyri, 1893: 84). The progress of society was the result of a series of advances amongst which were ones which affected women.

At a time when public administrations were increasing services for their citizens and they required people to manage them, women broke down the barriers of suspicion and insecurity raised by the extradomestic work of these "modern women"; this affected family dynamics, the perception of their self-esteem and, of course, a social organization which depended on mother-wives to conserve and transmit the scale of values of the patriarchal system at the time.

Thus, not being able to break this current of social progress, they tried to delimit the type and scope of the professions which were appropriate for women whose education had clearly exceeded what could have been imagined up until that time.

The women doctors exercised their profession either in private surgeries, charity hospitals or general care: the ophthalmologist Trinidad Arroyo (Márquez, 2010), the gynecologist Concepción Alexandre, the university professor of Medicine Elisa Fernández de la Vega or the Merchant Navy doctor Cecilia García de Cosa (Falá, 1934). Most of those who completed Pharmacy opened Chemist's: Gertrudis Martínez, Magdalena Fernández de la Cerda, Catalina Llabrés or Concepción Lazárraga. Those who completed Philosophy and Letters found it more difficult to find employment until after 1910 when the right of female graduates to occupy posts in the public administrations was recognised. Julio Burell, Minister of Public Instruction, stated that "The possession of diverse academic qualifications will enable women to work in the professions related to the Ministry of Public Instruction. ${ }^{9}$ " One of these was teaching at university, and the first to do so was Luisa Cuesta Gutiérrez (Valladolid, 1892-Madrid, 1962) at the University of Valladolid-, but they also took up jobs in secondary schools - Julia Gomis Llopis in 1911- and in libraries, museums and archives where Ángela García Rives won a place in 1913, etc.

The number of women going to university gradually increased in tune with the changing circumstances of those years. The twenty-one students in 1909-1910, rose to forty-four in 1911-1912, ninety in 1914-1915, 234 in 1917-1918, and 440 in 1920-1921. As the twentieth century progressed, the number of women continued to grow in absolute numbers and also as a percentage: in 19351936 female students represented $8.80 \%$ of the university population with a presence in all faculties (Flecha, 2008: 15-37). Similarly, after 1939, not even the dictatorship of General Franco stopped this increase, although the rate of increase did slow down, in comparison to other countries. Fifty per-cent was reached in 1986-1987, and that continues to be roughly the current situation.

\section{Female Lecturers in University Classrooms}

Throughout the $20^{\text {th }}$ century the presence of female students in absolute numbers and as a percentage did not correspond to the proportion of female teachers. An attempt was made to explain this by arguing that women had started working in universities much later than the first female students. However, the information contained in the archives paints a different picture because a woman started teaching at the University of Madrid as early as 1916. As a century has elapsed since that event, the current percentages and the academic posts occupied by women show that there are still obstacles to be overcome.

The first known teacher was the writer Emilia Pardo Bazán (La Coruña, 1851-Madrid, 1921) who was appointed professor by the Ministry of Public Instruction due to her literary merits. ${ }^{10}$ This woman of letters had not received a formal university education, but her intellectual capabilities meant that they applied a norm which regulated this type of incorporation to teach a subject in the doctorate course. In her case it was "Contemporary Literature of Neo-Latin Languages" at the Faculty of Philosophy and Letters at the Universidad Central. Neither the Faculty Board nor the members of the Royal Academy of 
Spain gave their consent in a consultation which was compulsory but not binding. Her appointment was also received with reticence by the students of whom only a very small number went to her classes, but she did have an audience of the general public who went to her classes (Quesada, 2006: 43-81). The firm attitude of this teacher served to encourage those that followed her.

In 1918 the University of Valladolid named as a professor Luisa Cuesta Gutiérrez (Medina de Rioseco, Valladolid, 1892-Madrid, 1962), who had graduated in Philosophy and Letters, History Section, with Distinction and an Award for Outstanding Achievement (Quesada, 2006: 43-81). The Board of the Faculty of Philosophy and Letters put her name forward and she was appointed as an unpaid auxiliary intern by the Rector of the University, "for the service of teaching during the present academic year. ${ }^{11} "$ The recent female graduate was given the task of teaching the subjects of Political and Descriptive Geography, and Palaeography. ${ }^{12}$

Three months earlier the Civil Servants Act had been passed which, on the basis of equal conditions for men and women, included some restrictions for access to occupational categories reserved for specialist technicians, ${ }^{13}$ although this was not the case in the Ministry of Public Instruction and Fine Arts. But it did create the possibility of entering other Ministries and public bodies, accelerating access to segments of the labour market where qualified women could work.

Roughly one hundred female graduates and $\mathrm{PhD}$ holders went into university teaching before 1939 (Flecha, 2010: 255-297). Teachers and researchers in all the university faculties of the day -Philosophy and Letters, Medicine, Law, Science and Pharmacy- with an unequal distribution in each one. But the difficult path to reaching a permanent post in the university meant that many opted to take state exams for other levels of teaching and for Libraries, Archives and Museums; while the doctors and pharmacists opted to freely exercise their professions.

The case of Luisa Cuesta provides a good example. In 1921 she passed the state exam to enter the library, archives and museums service and took up her post at the library of the Univesity of Santiago de Compostela. She combined this job with a teaching role in the Faculty of Galician Philosophy and Letters. ${ }^{14}$ A transfer in 1930 took her to the National Library in Madrid where she also taught at the Law Faculty, but she soon opted out of her university teaching roles.

A similar story occurred with the rest of the female university teachers during this period. The difficulties they encountered in a highly qualified professional itinerary ended up becoming an obstacle. Many chose not to remain in university teaching: they did not want to postpone any further their occupational stability in order to make decisions about other areas of their own lives which they did not wish to renounce. Of the hundred that went into university teaching only ten continued.

The reality of these women is pithily expressed by Emilia Pardo Bazán in a quote I like to repeat: "Everything is so difficult for us that it makes even the smallest triumph more valuable" (Bravo, 1973: 295). As in other areas, the processes in the university were costly, demanding strong wills and undespairing perseverance. Hence, each small step represented a triumph.

\section{Commitment to Oneself and to Society}

These women were exceptional because they received an excellent education went on to enjoy successful careers, and their study shows that they received prestige and were rewarded at different moments in their lives. They did not renounce the effort to do a degree, they were actively involved in the defense of a woman's right to higher education and remunerated work; and they applied these principles to themselves and spoke out about this in interviews, congresses and publications.

The knowledge acquired ensured they had sufficient merits to assume roles in the public arena, although they had to adapt to the conditions, values and attitudes of a male occupational culture, constructed for its natural recipients. They also had to make sacrifices, because that world was impervious to even the slightest modification. Even so, time has shown that this education helped innumerable women not just intellectually and professionally, but also to become aware of how their lives were programmed from the outside. This strengthened their will to introduce changes to the orders they received. The years of study constituted vital and valuable mediation.

This experience enabled them to demonstrate and legitimize the desire to distance themselves from imposed positions with no margin for doubt, from apparently objective arguments presented as undeniable truths, and from the artificial attribution of universal and uniform feminine characteristics. Reviewing the specific experiences of these women allows us to appreciate the limits of the explanatory models constructed on preconceptions so often based on stereotypes. It also rectifies the belief that all women have always submitted docilely to the set of mandates they received.

Greater visibility and recognition have undoubtedly been given to those feminine behaviours which fitted established norms, or to those which only on exceptional occasions visibly opposed the prototype expected of women. But it is clear that on more occasions than we know or can even imagine, proof of which are these first generations of female university students, there were young women who demonstrated great determination and did not give up, in keeping with their conscience, what they believed to be their right.

Individually, and knowing they were not alone, middle-class women started to adopt attitudes which widened the scope of their biographical journeys, as they took on responsibilities in social initiatives, as they grew as students in higher education, and undertook remunerated employment. Personal autonomy, freedom to choose their status and listening to their own feelings opened the way in women's circles in the years around the turn of the century. These contributions form part of the valuable legacy left by the women who preceded us, and they bear wit- 
ness to their capacity, consistency and inner liberty, amidst the most varying and unfavourable circumstances.

Hence the objective of recovering a past which provides certainty and transmits the desire to act today, in the $21^{\text {st }}$ century, when it is just as complicated although the explanatory reasons have changed and some barriers have been overcome. Because the certainty of having one's own genealogy, frees one from the vertigo of singularity, explores the roots which feed desires, emboldens expectations, speaks of effort to advance and insist on values which cannot easily be renounced without affecting what is most humane to each person.

Drawing on documentary sources from libraries, university archives, and newspaper libraries, in this article we present a historiographic perspective of women's history with the history of education. We have written an account of the journey followed by female university students determined to change the direction of their lives, undaunted by the many obstacles in their way.

This historical overview of women at university across several countries in the 19th century brings to light certain common threads:

- Registering for university was beset by a variety of obstacles, with much depending on the predisposition of the educational authorities in each country and the prevailing generalized mentality about the female condition. These women had to adopt pragmatic strategies such as opting for a specific faculty, pursuing legal action, travelling to countries where they were admitted by universities, and opting for viable professional spaces.

- From the outset, their decisions were determined by a social differentiation by gender of knowledge and the exercise of professional practice.

- Once at university, they received the support of family members, and parents from the burgeoning middle classes with a desire to give their daughters new opportunities; they were even supported by their husbands regarding professional practice.

- Most of the first female undergraduates took degrees related to Health Sciences, particularly Medicine, and they went into professional areas which did not represent an abrupt rupture with preconceptions about their nature.

- They generated and contributed to the social debate surrounding women's capacity to undertake university studies and whether this was appropriate.

- Some were familiar with the degrees chosen or benefited from an open intellectual environment, with family members in the profession, or they moved in social and political circles with broad cultural interests.

- It was common for them to analyse the problems faced by women, especially in education, in theses and publications. It could be said that these students laid the foundation for gender and education studies.

- They took advantage of loopholes in the prevailing gender system to study, practice professionally and intervene actively in society, overcoming obstacles and resistance.

This historical account of women at university shows that they had to use all their ingenuity to sidestep the mechanisms of exclusion-inclusion. They achieved this by juggling their own intentions with what was "allowed" in a harsh socio-cultural context. Many of these early female undergraduates were fully aware of this discrimination towards women and they made it their business to fight against it actively, albeit with varying degrees of commitment.

Women have always assumed a wide range of identities; had this not been the case it would be difficult to explain such insistent messages about how they should appear, the roles that correspond to them, the behaviours they should avoid, the destiny that awaits them. These insistent norms suggest that identical memories and trajectories cannot be accepted across the board for the entire female population.

There is a pressing need to uncover a past with too many dark areas and, at the same time, find a way of communicating this that does justice to the variety of contributions made by women.

This is our duty because by putting a face on the women who form part of our ancestry, we do not just recover inspiring experiences, we also earn respect and liberty for the women who are committed to overcoming the obstacles, some visible others not, which still thwart the projects of too many women in the world today.

\section{NOTES}

1 Correo de Comercio, 1, 21, 21 julio 1810: 166-168; y 1, 22, 28 de julio 1810: 169-170.

2 La Aljaba (1830) "Educación de las hijas", 3, 23 noviembre: 39.

3 La Aljaba (1830) "A los que se oponen a la instrucción de las mujeres", 4, 26 noviembre: 43.

4 Ministry of Justice, Worship and Public Education, Chile. Decree of February 6th 1877: 'Women exams to obtain professional degrees'. Bulletin of Government Laws and Decrees, Lib. XLV, 1877: 55-56.

5 Crónica Médica (1877) "Una Doctora en Medicina", Gaceta Médica de México, 9 septiembre: 339.

6 El Observador Americano (1816) "Educación de las Mujeres", Buenos Aires, 19 agosto: 4

7 The first ones were, in Medicine Dolores Aleu and Martina Castells, who applied for the certificate in November 1882. In Philosophy and Letters Ángela Carraffa de Nava in December 1892 and Matilde Padrós in April 1893.

8 The Royal Decree of 18 June 1852 on State Civil Servants used only the masculine form throughout the text, with no reference to possible female employees. (Gaceta de Madrid, 6572, 20 June: 1-2. The Law of Public Instruction of 1857, in Section Three 'Del profesorado público' [About state teachers], only refers to female teachers in primary education. (Gaceta de Madrid, 1710, 10 September: 2-3.

9 Royal Order 2 September 1910. Gaceta de Madrid, 246, 4 September: 731

10 Royal Decree 12 May 1916 of the Ministry of Public Instruction and Fine Arts, appointing Emilia Pardo Bazán, Countess of Pardo Bazán, full professor of Contemporary Literature of NeoLatin Languages in Gaceta de Madrid, 135, 14 May: 295.

11 Archives of the University of Valladolid (AUVA). Minutes of Rectorate meeting of 18 November 1918. Literature Degree Report. File 681-2. A Royal Order of 3 September 1915 was ap- 
plied, according to which auxiliary interns did not receive financial remuneration, although it was considered as a merit when applying for a temporary auxiliary post.

12 AUVA. Book 306: Minutes of the Faculty of Philosophy and Letters. Session on 15 November 1918, sheet 43.

13 Law of 22 July 1918 of "Rules for the condition of civil servants of the State Civil Administration", Gaceta de Madrid, 205, 24 July.

14 At the same time, she did her degree in law and prepared her doctoral thesis, which she read in 1927 on "La Gasca in America: a contribution to the study of the colonizing policy of Spain in America during the $16^{\text {th }}$ century"; about a cleric, Pedro la Gasca, an envoy of the King of Spain in Peru, he was known as "the pacifier". She published the thesis one year later: Luisa Cuesta Gutiérrez, La Obra de D. Pedro de La Gasca en América: contribución al estudio de la política colonizadora de España en América durante el siglo XVI. Santiago de Compostela: Tip. El Eco Franciscano, 1928.

\section{REFERENCES}

Addeo, Piero (1939) Eva togata. Editrice Rispoli, Napoli.

Barrancos, Dora (2000) "Inferioridad jurídica y encierro doméstico". In Historia de las Mujeres en la Argentina. TI. Colonia y siglo XIX, dirs. Gil Lozano, Fernanda; Piya, Valeria y Ini, María Gabriela. Taurus, Buenos Aires: 111-129.

Bieber, Florian and Heppner, Harald (eds.) (2015) Universities and elite formation in Central, Eastern and South Eastern Europe. Lit Verlag, Zürich.

Cruz Rodríguez, María Alcázar y Díez Bedmar, María Consuelo (2012) "Mujeres, educación y ciudadanía en el pensamiento liberal decimonónico. El caso de la Constitución de 1812". In Sobre un hito jurídico, la Constitución de 1812: reflexiones actuales, estados de la cuestión, debates historiográficos, eds. Chamocho Cantudo, Ángel y Lozano Miralles, Jorge. Universidad de Jaén, Jaén: 689-710.

Boa, Hebe C. y Costa, Viagem A. (2005) Elas, As Pioneiras do Brasil. Scortecci, São Paolo.

Bonder, Gloria (1992) "Las mujeres y la educación en Argentina: realidades, ficciones y conflictos de las mujeres universitarias". In La mujer y la violencia invisible, comps. Eva Giberti, Ana María Fernández. $2^{a}$ ed. Ed. Sudamericana: Buenos Aires: 3762.

Brandau G., Matilde (1898) Derechos civiles de la mujer. Imprenta Cervantes, Santiago.

Bravo Villasante, Carmen (1973) Vida y obra de Emilia Pardo Bazán. Magisterio Español, Madrid.

Camps i Lasa, Judith y Casasus i Fa, Marta (2000) "Aportacio al coneixement de la doctora Dolors Aleu i Riera, metgessa catalana (1857-1913)". Gimbernat, 34:165-176.

Carrillo-Esper, Raúl; Torre León, Teresa de la; Espinoza de los Monteros, Isis y Carrillo Córdova, Dulce María (2015) "Matilde Petra Montoya Lafragua. Breve historia de una mexicana ejemplar". Revista Mexicana de Anestesiología, 38, 3, JulioSeptiembre: 161-165.

Carlson, Marifran (1988) ¡Feminismo! The Woman's Movement in Argentina. Academy Chicago Publishers, Chicago.

Casals Bergés, Quintí (2017) "El acceso de las mujeres a la Universidad en España: el caso de las primeras universitarias leridanas (1882-1920)". Cuadernos del Instituto Antonio de Nebrija de Estudios sobre la Universidad, 20, 2: 275-301.

Castañeda López, Gabriela y Rodríguez Romo, Ana Cecilia (2010) Pioneras de la medicina mexicana en la UNAM: del Porfiriato al nuevo régimen, 1887-1936. Ediciones Díaz de Santos, México.

Colling, Ana María (2011) "As primeiras médicas brasileiras: mulheres à frente de seu tempo". Revista Fronteiras, Dourados, MS, 13, 24, jul.-dez.: 169-183.

Davidson, Jonathan (2014) A Century of Homeopaths: Their Influence on Medicine and Health. Springer, New York.

Díaz, Eloísa R. (1888) Breves observaciones sobre la aparición de la pubertad en la mujer chilena y de las predisposiciones patológicas propias del sexo. Memoria para optar al grado de Licenciado en la Facultad de Medicina y Farmacia. Leída el 25 de diciembre de 1886. Imprenta Nacional, Santiago de Chile, 27 pp.

Díaz, Hector (2007) "Primera médica peruana, Dra. Laura Esther Rodríguez Dulanto (1872-1919)". Anales de la Facultad de Medicina, Lima, 68, 2, abril-junio: 181-184.

El Caballero audaz (1914) "Nuestras visitas. Condesa de Pardo Bazán”. La Esfera, 14 de febrero: 8-9.

Falá, Juan (1934) "Nuestras interviús (sic) Cecilia García de Cosa". España Médica, Madrid, XXV, 643, abril: 11-12.

Flecha García, Consuelo (1993) "Cultura y feminismo en la historia de las universitarias argentinas". Revista Espacio y Tiempo, Universidad de Sevilla, 7: 89-101.

Flecha García, Consuelo (1996) Las primeras universitarias en España. Narcea, Madrid.

Flecha García, Consuelo (2006) "Mujeres en Institutos y Universidades". In Historia de las Mujeres en España y América Latina. TIII: Del siglo XIX a los umbrales del XX, coords. Gómez-Ferrer, Guadalupe; Cano, Gabriela; Barrancos, Dora y Lavrin, Asunción. Cátedra, Madrid: 455-485.

Flecha García, Consuelo (2010) "Profesoras en la Universidad. El tránsito de las pioneras en España”. Arenal, 17, 2: 255-297.

Flecha García, Consuelo (2016) "Memoria de mujeres pioneras: universitarias en Andalucía". In Renovación en las aulas. La Institución Libre de Enseñanza en Andalucía, coord. Encarnación Lemus. Centro de Estudios Andaluces, Sevilla: 67-92.

Flores Gutiérrez, Sonia C. y Ramos R., Mariblanca (2000) "La mujer y las ciencias de la salud, durante el siglo XIX". Revista Facultad de Medicina, UNAM, 43, 6, noviembre-diciembre: 230-233.

Gabriel, Narciso de (1997) "Alfabetización, semialfabetización y analfabetismo en España (1860-1991)". Revista Complutense de Educación, 8, 1: 199-231.

García, Betsabé (2010) Juguen dames: les primeres universitàries: Helena Maseras, Dolors Aleu i Martina Castells, Ara Llibres, Badalona.

González Pérez, Teresa (2012) "La conquista de espacios del saber. Mujeres universitarias en Canarias durante la primera mitad del siglo XX". In Formación de élites y educación superior en Iberoamérica: (ss. XVI-XXI), coord. Hernández Díaz, José María, Hergar Ediciones Antema, Salamanca, 1: 543-554.

Goyri, María (1893) “Una Información”. La Escuela Moderna, 23, febrero: 84 .

Grierson, Cecilia (1916) Doctora Cecilia Grierson: Su obra y su vida. Imp. Tragant, Buenos Aires.

Gutiérrez, Tania. (2005) Trinidad Enríquez, Primera Universitaria $y$ precursora social peruana. Gutiérrez Samanez Editores, Cusco.

Hernández Galano, Yamilet (2012) "Descubriendo una nueva vida. Las primeras mujeres en la Universidad de La Habana (18831900)". Universidad de La Habana, 274, jul-dic: 140-153.

Jiménez Escobar, Alejandro (2000) "Dra. Eloísa Díaz Insunza". Revista Chilena de Infectología, 17, 1: 76-78.

Juan Castrillo, Albano de (2015) "Las primeras mujeres médicas palentinas". In La Residencia de Señoritas y otras redes culturales femeninas, eds. Cuesta, Josefina, Turrión, María José y Merino, Rosa María, Universidad de Salamanca; Fundación Ortega y Gasset, Salamanca-Madrid: 339-360.

Kohn Loncarica, Alfredo y Sánchez, Norma Isabel (1996) "La mujer en la medicina argentina: las médicas de la primera década del siglo XX". Saber y Tiempo. Revista de Historia de la Ciencia, Buenos Aires, 1, 2: 113-138.

Kohn Loncarica, Alfredo y Sánchez, Norma Isabel (2000) "La mujer en la medicina argentina: las médicas de la segunda década del siglo XX". Saber y Tiempo. Revista de Historia de la Ciencia, Buenos Aires, 3, 9: 89-107.

León, María Teresa (1998) Memoria de la melancolía. Castalia, Madrid.

López Espinosa, José Antonio (2004) "La primera mujer cubana graduada de médico en la Universidad de La Habana". Revista Cubana de Medicina General Integral, La Habana, 20, 2, marzoabril. Recuperado de http://scielo.sld.cu/scielo.php?script=sci arttext\&pid=S0864-21252004000200014\&lng=es\&tlng=es. [consultado 29/November/2017] 
Macías, Anna (2002) Contra viento y marea: El Movimiento Feminista en México hasta 1940. CIESAS UNAM, México.

Marchante Castellanos, Pilar y Merchán González, Francisco (2012) "Las primeras cubanas graduadas de Farmacia". Revista Cubana de Farmacia, 46, 1:117-126.

Márquez Arroyo, Cristina (2010) "Trinidad Arroyo de Márquez (1872-1959): primera oftalmóloga española, políglota, redactora médica y una mujer de armas tomar". Panace@, XI, 31: 101-110.

Miqueo Miqueo, Consuelo (2015) "Seducidas por la ciencia. La integración de las mujeres en la Facultad de Medicina de la Universidad de Zaragoza durante el siglo XX". In La Residencia de Señoritas y otras redes culturales femeninas, (eds.) Cuesta, Josefina; Turrión, María José y Merino, Rosa María, Universidad de Salamanca y Fundación Ortega y Gasset, Salamanca-Madrid: 361-406.

Morgade, Graciela (1997) Mujeres en la educación. Género y docencia en Argentina: 1870-1930. Miño y Dávila Editores, Buenos Aires.

Navarro, Marysa y Sánchez Korrol, Virginia (2004) Mujeres en América Latina y el Caribe, Narcea Madrid.

Offen, Karen (2015) Feminismos europeos 1700-1950. Una historia política. Akal, Madrid.

Orellana Rivera, María Isabel (2015) Sentimientos en busca de ciencia: inicios de la educación científica femenina en Chile (1870-1930). Dibam y Museo de Educación Gabriela Mistral, Santiago de Chile.

Palacio de Azara, Dolores de y Sánchez-Reyes, Carlos (2010) Memorias de una mujer catedrático, Ed. C. Sánchez-Reyes, Madrid.

Palermo, Alicia I. (2006) "El acceso de las mujeres a la educación universitaria". Revista Argentina de Sociología, Buenos Aires, 4, 7: 11-46.

Prado Herrera, María Luz de (2015) "Tres universitarias excepcionales eccn la Salamanca de principios del siglo XX”. In ¿Mujeres sabias? Mujeres universitarias en España y América Lati$n a$, (coords.) Cuesta, Josefina; De Prado, María Luz y Rodríguez, Francisco J., Presses Universitaires de Limoges, Limoges: $123-158$.
Quesada Novás, Ángeles (2006) "Una meta alcanzada: La cátedra universitaria de Emilia Pardo Bazán”. La Tribuna, 4: 43-81.

Rago, Elisabeth Juliska (2000) "A ruptura do mundo masculino da medicina: médicas brasileiras no século XIX". Cadernos Pagu, 15: $199-225$.

Rama, Germán (1987) Desarrollo y educación en América Latina y el Caribe. Kapelusz, Buenos Aires.

Rivera Garretas, María-Milagros (1997) "Oliva Sabuco de Nantes Barrera". In Breve historia feminista de la literatura española, coord. Zavala, Iris M., Anthropos, Barcelona, 4: 131-146.

Rivera Garretas, María-Milagros (2005) La diferencia sexual en la historia. Publicaciones Universidad de Valencia, Valencia.

Sánchez, Norma I.; Provenzano, Sergio y Pérgola, Federico (2015) Las primeras mujeres de la medicina universitaria argentina 1889-1950. Editorial Alfredo Buzzi, Buenos Aires.

Sánchez Manríquez, Karin (2006) "El ingreso de la mujer chilena a la Universidad y los cambios en la costumbre por medio de la Ley 1872-1877". Historia, Santiago, 39, 2, julio-diciembre: 497-529.

Suárez, Paula (2012) "Las mujeres abogadas en la historia y en la Facultad de Derecho de la Universidad de Buenos Aires". Academia, Revista sobre enseñanza del derecho, Buenos Aires, Argentina, 10, 12: 143-183.

Taylor Kirschmann, Anne (2003) A Vital Force: Women in American Homeopathy. Rutgers University Press, New Brunswick, New Jersey and London: 58-62.

Valladares Chamorro, Odalis (2012) "La incursión de las mujeres a los estudios universitarios en el Perú: 1875-1908". Cuadernos del Instituto Antonio de Nebrija, 15, 1: 105-123.

Verdugo Martí, Vicenta (2013) "Pioneras universitarias: las primeras mujeres de la Universidad de Valencia". In La Constitución de Cádiz: genealogía y desarrollo del sistema educativo liberal, (eds.) Espigado Tocino, M. Gloria; Fernández Gómez Sánchez, Juan; Pascua, María José de la; Sánchez Villanueva, Juan Luis y Vázquez Domínguez, Carmen, Universidad de Cádiz, Cádiz: 785-798. 